
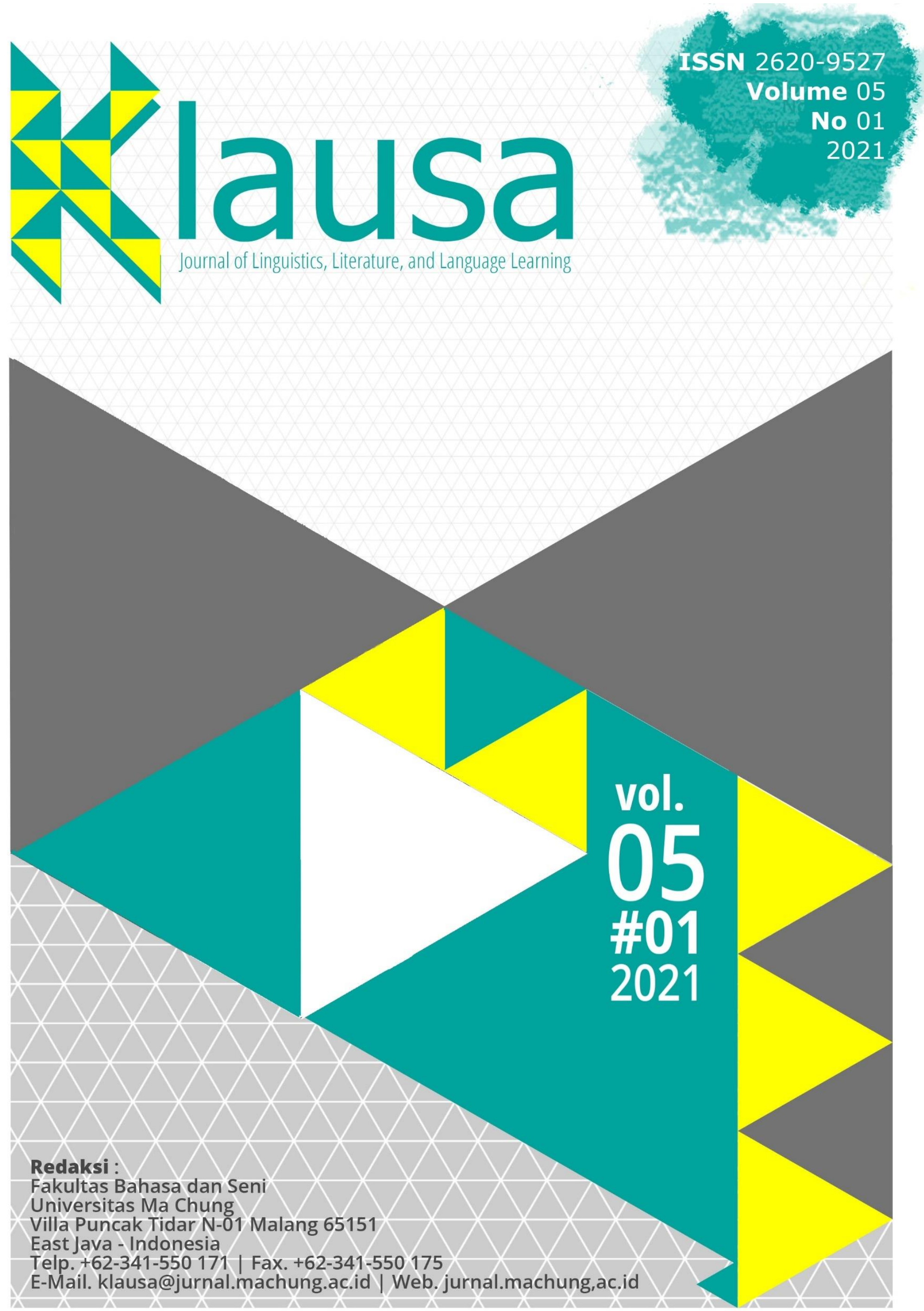
ISSN: $\quad 2301-4822(p)$

DOI: $\quad$ 10.33479/klausa.v4i02

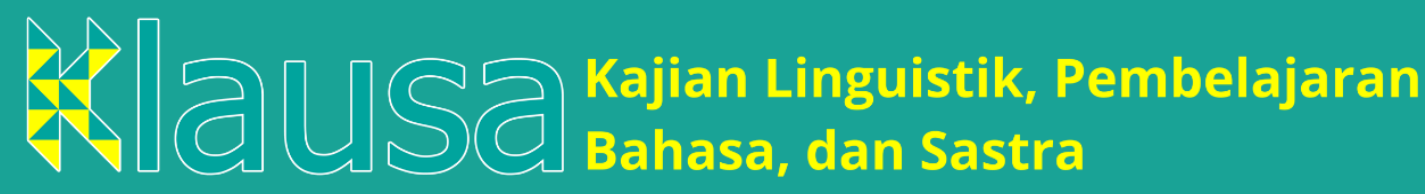

\section{Editorial Team}

$\begin{array}{ll}\text { Editor-in-Chief } & : \text { Dr. Daniel Ginting } \\ \text { Journal Manager } & : \text { Wawan Eko Yulianto, Ph.D. } \\ \text { Editors } & \text { Prof. Dr. Patrisius I. Djiwandono } \\ & \text { Lilis Lestari Wilujeng, M.Hum. } \\ \text { Reviewers } & \text { F.X Dono Sunardi, M.A. } \\ & \text { Dhatu Sitaresmi, MTCSOL. } \\ & \text { Anggrah Diah Arlinda, MTCSOL. } \\ & \text { Yohanna Nirmalasari, S.Pd., M.Pd. } \\ & \text { Prof. A. Effendi Kadarisman, Ph.D. } \\ & \text { Sisilia Halim, Ph.D. } \\ & \text { Dr. Mundi Rahayu } \\ & \text { Dr. Ross Wood } \\ & \text { Dr. Leticia Araceli Salas Serrano } \\ & \text { Faculty of Language and Arts } \\ & \text { Universitsas Ma Chung } \\ \text { Frequency } & \text { The Faculty of Language and Arts } \\ \text { Mublisher } & \text { Ma Chung University } \\ & \text { Villa Puncak Tidar N-01 (65151) } \\ & \text { Malang, East Java, Indonesia } \\ & \text { Email: jurnal.klausa@machung.ac.id } \\ & \text { Twice a year } \\ \text { Address } & \end{array}$




\section{CONTENTS}

FOREWORD

iii

MANAGEMENT OF POLITENESS STRATEGIES AND RHETORICAL DEVICES IN DONALD TRUMP'S SPEECHES DURING THE CONFLICT WITH IRAN: PRAGMATIC VIEW

Khoirun Nisak, Lisetyo Ariyanti

PERBANDINGAN UNSUR PEMBANGUN CERITA NOVEL DAN FILM SANG PEMIMPI

Muhamad Deni Setiawan. 19

HALF-CASTE'S STATE OF LIMBO IN KATHARINE SUSANNAH PRICHARD'S “MARLENE” AND “FLIGHT” (1967)

Laily Ramadhani, Mamik Tri Wedawati. 29

ANALISIS KUALITAS TERJEMAHAN TEKS BAHASA JEPANG KE BAHASA INDONESIA DENGAN BING TRANSLATOR

Wisnu Setya Budi, Febi Ariani Saragih 45

印尼玛中大学汉语学习者词汇学习策略调查研究

Vincentius Valiandy Jiuangga,S.Kom.,MTCSOL 63 


\title{
ANALISIS KUALITAS TERJEMAHAN TEKS BAHASA JEPANG KE BAHASA INDONESIA DENGAN BING TRANSLATOR
}

\author{
Wisnu Setya Budi ${ }^{1}$, Febi Ariani Saragih ${ }^{2}$ \\ ${ }^{1}$ Universitas Brawijaya, wisnusb@student.ub.ac.id \\ 2Universitas Brawijaya, emiwk74@ub.ac.id
}

\begin{abstract}
ABSTRAK
Seiring perkembangan zaman, bermunculan teknologi yang memudahkan manusia di berbagai bidang. Salah satunya adalah di bidang penerjemahan, dengan munculnya mesin penerjemah otomatis. Kemunculan mesin penerjemah otomatis tersebut membuat kegiatan menerjemahkan menjadi semakin mudah dan praktis. Bing Translator sebagai salah satu mesin penerjemah otomatis memiliki kemampuan menerjemahkan teks bahasa Jepang ke bahasa Indonesia. Namun, kualitas mesin penerjemah ini masih diragukan. Karena itu dibutuhkan penelitian lebih lanjut terkait kualitas terjemahan mesin penerjemah. Penelitian ini bertujuan untuk megidentifikasi dan mendeskripsikan kualitas mesin penerjemah Bing Translator dengan menggunakan metode penilaian terjemahan Nababan yang meliputi: keakuratan, keberterimaan, dan keterbacaan. Pendekatan kualitatif deskriptif dan analisis dokumen digunakan pada penelitian ini. Data penelitian diperoleh dari hasil analisis peneliti dan hasil validasi dari validator data. Dalam menganalisis data, peneliti menggunakan metode perbandingan tetap yang digagas oleh Glaser. Hasil penelitian menunjukkan bahwa berita ekonomi memiliki tingkat keakuratan sedang, kurang berterima, dan keterbacaan sedang. Berita politik memiliki tingkat keakuratan sedang, tidak berterima dan keterbacaan rendah. Berita kesehatan memiliki tingkat keakuratan sedang, kurang berterima, dan keterbacaan rendah.
\end{abstract}

Kata kunci: penerjemahan, mesin penerjemah, keakuratan, keberterimaan, keterbacaan

\section{PENDAHULUAN}

Mesin penerjemah otomatis diciptakan dengan tujuan mempermudah kegiatan penerjemahan, termasuk menerjemahkan teks berbahasa Jepang ke dalam bahasa Indonesia. Mesin penerjemah merupakan sebuah software atau piranti lunak komputer 
yang bertugas menerjemahkan teks dari satu bahasa ke bahasa lain (Localization Industry Standards Association [LISA], 2010). Penerjemahan adalah proses memproduksi ulang pesan dalam BSu ke BSa (Nida, 1969). Jenis teks yang paling sering diterjemahkan dengan menggunakan mesin adalah teks berita. Berita merupakan laporan tercepat dari suatu peristiwa menurut Willard C. Bleyer (dikutip dari Romli, 2009, hlm. 35). Salah satu mesin penerjemah yang paling sering digunakan yaitu Bing Translator, yang merupakan mesin penerjemah besutan Microsoft yang dapat menerjemahkan lebih dari 70 bahasa termasuk menerjemahkan bahasa Jepang ke dalam bahasa Indonesia. Walaupun menawarkan kemudahan serta kepraktisan, kualitas terjemahan mesin masih dipertanyakan. Kualitas terjemahan sendiri bisa dinilai berdasarkan aspek keakuratan, keberterimaan, dan keterbacaannya. Keakuratan mengacu pada kesepadanan atau kesamaan antara BSu dan BSa. Keberterimaan mengacu pada apakah suatu terjemahan sudah diungkapkan sesuai kaidah-kaidah, norma dan budaya BSa. Keterbacaan mengacu pada derajat kemudahan sebuah tulisan untuk dipahami maksudnya menurut Nababan (2003, hlm.62).

Berdasarkan pengalaman peneliti ketika menggunakan Bing Translator untuk menerjemahkan teks berita berbahasa Jepang ke dalam bahasa Indonesia, hasil terjemahan terkesan kurang alamiah dan membingungkan. Banyak terdapat pemadanan kata yang kurang tepat serta susunan kalimat masih mengikuti struktur gramatikal bahasa Jepang. Peneliti bertujuan untuk mengidentifikasikan dan mendeskripsikan keakuratan, keberterimaan, dan keterbacaan terjemahan mesin penerjemah Bing Translator.

\section{METODE PENELITIAN}

Metode yang digunakan pada penelitian ini yaitu deskriptif kualitatif dikarenakan data yang digunakan merupakan kata, frasa dan kalimat seperti yang dikatakan oleh Bogdan dan Taylor (dalam Moleong, 2010, hal. 4). Desain penelitian yang digunakan adalah studi kasus dengan teknik mengkaji dokumen. Kasus yang dimaksud disini adalah bagaimana hasil terjemahan Bing Translator dalam menerjemahkan teks berita bahasa Jepang ke dalam bahasa Indonesia.

Data dan sumber data pada penelitian ini yaitu semua kata, frasa, dan kalimat dari berita ekonomi, politik, dan kesehatan berbahasa Jepang yang bersumber dari portal berita Digima News serta hasil terjemahan bahasa Indonesianya dari Bing Translator. Untuk mengumpulkan data penelitian, digunakan teknik pengkajian dokumen yang memungkinkan untuk menemukan berbagai macam hal sesuai dengan kebutuhan dan tujuan penelitian seperti yang dikemukakan oleh Yin dalam Sutopo (2006, hal. 81). Yang pertama dilakukan yaitu paragraf pada teks berita ekonomi, politik, dan kesehatan berbahasa Jepang yang bersumber dari Digima News dibagi ke dalam beberapa segmen. Kedua, teks berita asli dalam bahasa Jepang dan hasil terjemahan bahasa Indonesianya dari Bing Translator dibaca dan dibandingkan. Ketiga, menandai tiap frasa, kalimat, dan 
klausa pada tiap segmen. Keempat, melakukan pengumpulan, pencatatan dan klasifikasi data dan menganalisis keakuratan, keberterimaan, dan keterbacaan terjemahan teks berita dari masing-masing teks berita. Terakhir, menarik kesimpulan.

Untuk menganalisis data digunakan metode perbandingan tetap (Constant Comparative Method) yang mencakup: reduksi data, kategorisasi data, sintesiasi data, dan penyusunan hipotesis kerja. Pada tahap reduksi data, berita dibedakan dan diberi kode berdasarkan topiknya, yaitu berita ekonomi (BE), politik (BP), dan kesehatan (BK), lalu membaginya ke dalam beberapa segmen berdasarkan paragrafnya. Selanjutnya pada tahap kategorisasi data, tiap data dibagi dan dilabeli berdasarkan keakuratan, keberterimaan, dan keterbacaan. Berikutnya pada tahap sintesiasi data, data dianalisis dengan menggunakan metode penilaian terjemahan Nababan.

\section{TEMUAN DAN PEMBAHASAN}

\section{Temuan}

\section{Keakuratan}

Untuk menganalisis segi keakuratan terjemahan digunakan indikator penilaian tingkat keakuratan sebagai berikut.

\section{Tabel 1. Instrumen Penilaian Tingkat Keakuratan Terjemahan}

\begin{tabular}{|l|l|l|}
\hline Kesimpulan & Skala & \multicolumn{1}{c|}{ Indikator } \\
\hline Akurat & 3 & $\begin{array}{l}\text { Makna kata, frasa, klausa, dan kalimat bahasa sumber } \\
\text { dialihkan secara akurat ke dalam Bsa. }\end{array}$ \\
\hline $\begin{array}{l}\text { Kurang } \\
\text { Akurat }\end{array}$ & 2 & $\begin{array}{l}\text { Sebagian besar makna kata, frasa, klausa dan kalimat BSu } \\
\text { sudah dialihkan secara akurat ke dalam BSa. Namun, masih } \\
\text { ada distorsi makna yang mengganggu keutuhan pesan }\end{array}$ \\
\hline $\begin{array}{l}\text { Tidak } \\
\text { Akurat }\end{array}$ & 1 & $\begin{array}{l}\text { Makna kata, frasa, klausa, dan kalimat bahasa sumber } \\
\text { dialihkan secara tidak akurat ke dalam BSu atau dihilangkan } \\
\text { (deleted) }\end{array}$ \\
\hline
\end{tabular}

Setelah menganalisis berita ekonomi, politik, dan kesehatan didapat temuan sebagai berikut.

Tabel 2. Tingkat Keakuratan Hasil Terjemahan Bing Translator

\begin{tabular}{|c|c|}
\hline \multicolumn{2}{|c|}{ Berita Ekonomi } \\
\hline Kode & Skor \\
\hline Judul BE & 2 \\
\hline BE 1.1 & 3 \\
\hline BE 1.2 & 2 \\
\hline BE 2.1 & 1 \\
\hline BE 3.1 & 1 \\
\hline
\end{tabular}

\begin{tabular}{|c|c|}
\hline \multicolumn{2}{|c|}{ Berita Politik } \\
\hline Kode & Skor \\
\hline Judul BP & 2 \\
\hline BP 1.1 & 2 \\
\hline BP 1.2 & 2 \\
\hline BP 2.1 & 2 \\
\hline BP 2.2 & 2 \\
\hline
\end{tabular}

\begin{tabular}{|c|c|}
\hline \multicolumn{2}{|c|}{ Berita Politik } \\
\hline Kode & Skor \\
\hline Judul BK & 1 \\
\hline BK 1.1 & 1 \\
\hline BK 2.1 & 2 \\
\hline BK 3.1 & 2 \\
\hline BK 4.1 & 2 \\
\hline
\end{tabular}




\begin{tabular}{|c|c|c|c|c|c|}
\hline BE 3.2 & 2 & BP 3.1 & 1 & BK 4.2 & 2 \\
\hline BE 3.3 & 2 & BP 4.1 & 1 & BK 5.1 & 1 \\
\hline BE 3.4 & 2 & BP 4.2 & 1 & & \\
\hline BE 4.1 & 1 & & & & \\
\hline BE 4.2 & 1 & & & & \\
\hline BE 5.1 & 2 & & & & \\
\hline
\end{tabular}

Berikut merupakan diagram yang menunjukkan perbandingan tingkat keakuratan dari berita ekonomi, politik, dan kesehatan.

\section{Diagram 1. Tingkat Keakuratan Hasil Terjemahan Bing Translator}

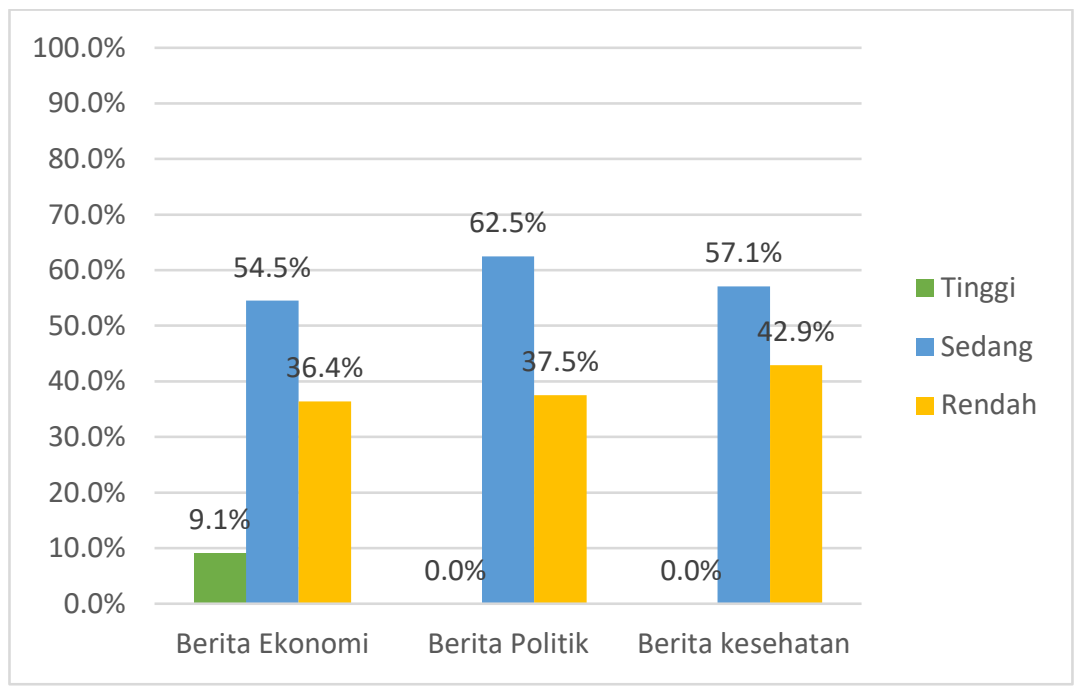

\section{Keberterimaan}

Untuk menganalisis segi keberterimaan terjemahan digunakan indikator penilaian tingkat keberterimaan sebagai berikut.

\section{Tabel 3. Instrumen Penilaian Tingkat Keberterimaan Terjemahan}

\begin{tabular}{|c|c|l|}
\hline Kesimpulan & Skala & \multicolumn{1}{|c|}{ Indikator } \\
\hline Berterima & 3 & $\begin{array}{l}\text { Terjemahan terasa alamiah, istilah yang digunakan lazim dan } \\
\text { sesuai dengan kaidah Bahasa Indonesia. }\end{array}$ \\
\hline $\begin{array}{c}\text { Kurang } \\
\text { Berterima }\end{array}$ & 2 & $\begin{array}{l}\text { Pada umumnya terjemahan sudah terasa alamiah, namun } \\
\text { ada sedikit masalah pada penggunaan istilah atau terjadi } \\
\text { sedikit kesalahan gramatikal. }\end{array}$ \\
\hline $\begin{array}{c}\text { Tidak } \\
\text { Berterima }\end{array}$ & 1 & $\begin{array}{l}\text { Terjemahan tidak alamiah atau terasa seperti karya } \\
\text { terjemahan, istilah yang digunakan tidak sesuai dengan kaidah } \\
\text { bahasa Indonesia. }\end{array}$ \\
\hline
\end{tabular}

Setelah melakukan analisis secara mendalam ditemukan data tingkat keberterimaan dari berita ekonomi, politik, dan kesehatan adalah sebagai berikut. 
Tabel 4. Tingkat Keberterimaan Hasil Terjemahan Bing Translator

\begin{tabular}{|c|c|}
\hline \multicolumn{2}{|c|}{ Berita Ekonomi } \\
\hline Kode & Skor \\
\hline Judul BE & 2 \\
\hline BE 1.1 & 2 \\
\hline BE 1.2 & 2 \\
\hline BE 2.1 & 2 \\
\hline BE 3.1 & 2 \\
\hline BE 3.2 & 2 \\
\hline BE 3.3 & 2 \\
\hline BE 3.4 & 2 \\
\hline BE 4.1 & 1 \\
\hline BE 4.2 & 1 \\
\hline BE 5.1 & 1 \\
\hline
\end{tabular}

\begin{tabular}{|c|c|}
\hline \multicolumn{2}{|c|}{ Berita Politik } \\
\hline Kode & Skor \\
\hline Judul BP & 2 \\
\hline BP 1.1 & 1 \\
\hline BP 1.2 & 3 \\
\hline BP 2.1 & 2 \\
\hline BP 2.2 & 2 \\
\hline BP 3.1 & 1 \\
\hline BP 4.1 & 1 \\
\hline BP 4.2 & 1 \\
\hline
\end{tabular}

\begin{tabular}{|c|c|}
\hline \multicolumn{2}{|c|}{ Berita Politik } \\
\hline Kode & Skor \\
\hline Judul BK & 2 \\
\hline BK 1.1 & 2 \\
\hline BK 2.1 & 2 \\
\hline BK 3.1 & 2 \\
\hline BK 4.1 & 2 \\
\hline BK 4.2 & 2 \\
\hline BK 5.1 & 1 \\
\hline
\end{tabular}

Berikut merupakan diagram yang menunjukkan perbandingan tingkat keakuratan dari berita ekonomi, politik, dan kesehatan.

\section{Diagram 2. Tingkat Keberterimaan Hasil Terjemahan Bing Translator}

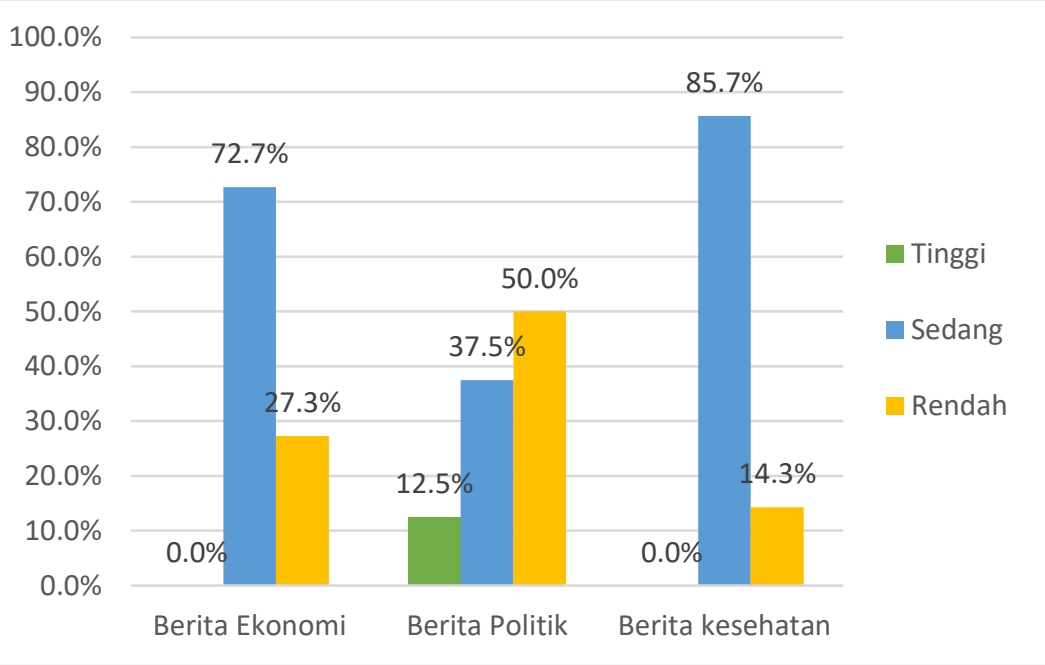

\section{Keakuratan}

Untuk menganalisis segi keterbacaan terjemahan digunakan indikator penilaian tingkat keterbacaan sebagai berikut.

\section{Tabel 5. Instrumen Penilaian Tingkat Keterbacaan Terjemahan}

\begin{tabular}{|c|c|l|}
\hline Kesimpulan & Skala & \multicolumn{1}{c|}{ Indikator } \\
\hline $\begin{array}{c}\text { Keterbacaan } \\
\text { tinggi }\end{array}$ & 3 & $\begin{array}{l}\text { Kata, frasa, klausa, dan kalimat terjemahan dapat dipahami } \\
\text { dengan mudah oleh pembaca. }\end{array}$ \\
\hline $\begin{array}{c}\text { Keterbacaan } \\
\text { sedang }\end{array}$ & 2 & $\begin{array}{l}\text { Pada umumnya terjemahan dapat dipahami oleh pebaca; } \\
\text { namun ada bagian tertentu yan gharus dibaca lebih dari satu } \\
\text { kali untuk memahami terjemahan. }\end{array}$ \\
\hline
\end{tabular}




\begin{tabular}{|c|c|c|}
\hline $\begin{array}{c}\text { Keterbacaan } \\
\text { rendah }\end{array}$ & 1 & Terjemahan sulit dipahami oleh pembaca. \\
\hline
\end{tabular}

Setelah melakukan analisis secara mendalam ditemukan data tingkat keterbacaan dari berita ekonomi, politik, dan kesehatan adalah sebagai berikut.

Tabel 6. Tingkat Keterbacaan Hasil Terjemahan Bing Translator

\begin{tabular}{|c|c|}
\hline \multicolumn{2}{|c|}{ Berita Ekonomi } \\
\hline Kode & Skor \\
\hline Judul BE & 2 \\
\hline BE 1.1 & 3 \\
\hline BE 1.2 & 2 \\
\hline BE 2.1 & 2 \\
\hline BE 3.1 & 3 \\
\hline BE 3.2 & 2 \\
\hline BE 3.3 & 2 \\
\hline BE 3.4 & 2 \\
\hline BE 4.1 & 1 \\
\hline BE 4.2 & 1 \\
\hline BE 5.1 & 1 \\
\hline
\end{tabular}

\begin{tabular}{|c|c|}
\hline \multicolumn{2}{|c|}{ Berita Politik } \\
\hline Kode & Skor \\
\hline Judul BP & 1 \\
\hline BP 1.1 & 1 \\
\hline BP 1.2 & 3 \\
\hline BP 2.1 & 3 \\
\hline BP 2.2 & 3 \\
\hline BP 3.1 & 1 \\
\hline BP 4.1 & 1 \\
\hline BP 4.2 & 1 \\
\hline
\end{tabular}

\begin{tabular}{|c|c|}
\hline \multicolumn{2}{|c|}{ Berita Politik } \\
\hline Kode & Skor \\
\hline Judul BK & 1 \\
\hline BK 1.1 & 2 \\
\hline BK 2.1 & 1 \\
\hline BK 3.1 & 1 \\
\hline BK 4.1 & 2 \\
\hline BK 4.2 & 2 \\
\hline BK 5.1 & 1 \\
\hline
\end{tabular}

Berikut merupakan diagram yang menunjukkan perbandingan tingkat keterbacaan dari berita ekonomi, politik, dan kesehatan.

\section{Diagram 2. Tingkat Keterbacaan Hasil Terjemahan Bing Translator}

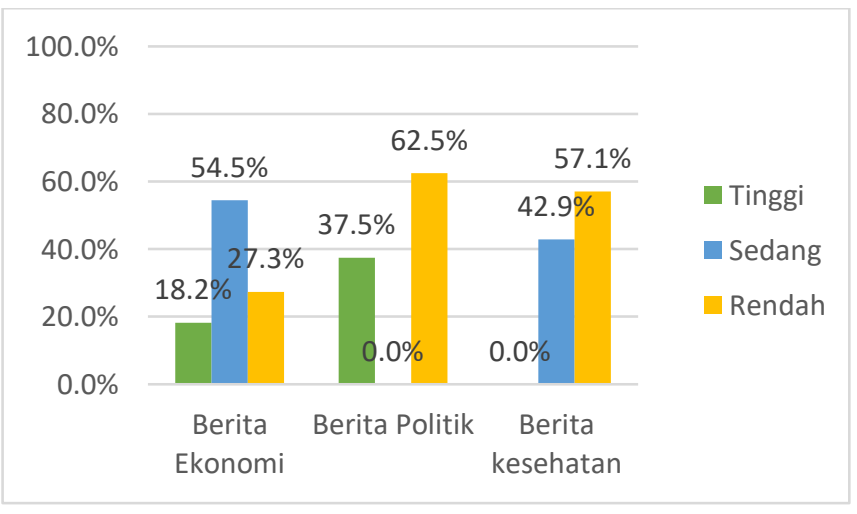

\section{Pembahasan}

\section{Keakuratan}

Untuk berita ekonomi, dalam terjemahan yang akurat hanya terdapat satu data yang masuk kategori ini, yaitu pada BE 1.1.

\begin{tabular}{|l|l|l|}
\hline $\mathrm{BE}$ & 観光庁は 6 月 17 日、2020 年 3 月 31 & Pada 17 Juni 2020, Badan Pariwisata Jepang \\
1.1 & 日時点での都道府県別消費税免税店数 \\
& をとりまとめ、発表した。 & $\begin{array}{l}\text { menyusun dan mengumumkan jumlah toko bebas } \\
\text { pajak konsumsi berdasarkan prefektur per } 31 \\
\text { Maret 2020. }\end{array}$ \\
\hline
\end{tabular}


Untuk terjemahan kurang akurat, yang termasuk kategori ini ditemukan sebanyak 6 nomor, yaitu: Judul BE, BE 1.2, BE 3.2, BE 3.3, BE 3.4, dan BE 5.1. Contohnya sebagai berikut.

\begin{tabular}{|c|l|l|l|}
\hline Judul & 国内の免税店数 前回調査から 4.7\%増の 5 万 & Jumlah toko bebas bea di Jepang: \\
BE & 4667 店に地方免税店は念願の目標 2 万店を達成 & $\begin{array}{l}54.667 \text { toko bebas bea lokal, naik 4,7\% } \\
\text { dari survei sebelumnya, mencapai } \\
\text { target jangka panjang 20.000. }\end{array}$ \\
\hline
\end{tabular}

Ada dua hal yang membuat makna kurang tersampaikan:

1. (Toko bebas bea lokal); lokal menunjukkan satu wilayah tertentu, sedangkan kata 国内 (kokunai) berarti dalam negeri (Jepang), bukan hanya satu wilayah tertentu yang ada di Jepang.

2. Kata 念願の目標 (Nengan no mokuhyō) seharusnya diterjemahkan menjadi target yang telah lama ingin dicapai atau target awal.

Untuk terjemahan tidak akurat, data yang termasuk terjemahan yang tidak akurat, yaitu data bernomor: BE 2.1, BE 3.1, BE 4.1, BE 4.2. Contohnya sebagai berikut.

\begin{tabular}{|l|l|l|}
\hline $\mathrm{BE}$ & 三大都市圈とそれを除く地方の免税店数をみると、 & Jumlah toko bebas bea di tiga wilayah \\
2.1 & 東京、神奈川、千葉、埼玉、愛知、大阪、京都、兵庫 & metropolitan utama dan wilayah lain \\
& の三大都市圏では前回調査から $5.1 \%$ 増の 3 万 & meningkat 5,1\% dari survei sebelumnya \\
& 3997 店になり、三大都市圏を除く地方では同期間 & menjadi 33.997 di tokyo, Kanagawa, \\
で 4.0\%増加、初めて 2 万店を突破し、2 万 670 & Chiba, Saitama, Aichi, Osaka, Kyoto, dan \\
& Hyogo, dan di wilayah ini tidak termasuk \\
& tiga wilayah metropolitan utama, jumlah \\
& toko bebas bea melebihi 20.000 untuk \\
& pertama kalinya, melebihi 20.670 toko. \\
\hline
\end{tabular}

Ada beberapa penghilangan kata dan membuat makna tidak akurat.

1. Frasa 三大都市圏とそれを除く地方の免税店数をみると (Sandaitoshi-ken to sore wo nozoku chihō no menzei-ten-sū wo miru to) seharusnya diterjemahkan menjadi Di wilayah selain tiga wilayah metropolitan utama. Namun frasa tersebut malah dihilangkan.

2. 前回調査から(Zenkai chōsa kara) kata dari di sini bukan menunjukkan tempat, melainkan waktu saat dilakukan survey.

3. を突破し (wo toppa shi) lebih baik jika diterjemahkan menjadi menembus atau melampaui.

4. Frasa 同期間で 4.0\%増加 (Dō kikan de 4. 0-Pāsento zōka) dihilangkan sehingga mengganggu keutuhan pesan.

5. Kata となった (to natta) bukan melebihi, melainkan menjadi. Partikel yang dipakai adalah と(to), menandakan menjadi, terlebih kata yang dipakai adalah なった (natta) yang memang berarti menjadi. 
Untuk berita politik, terjemahan yang akurat tidak terdapat satupun data yang termasuk ke dalam kategori akurat. Untuk terjemahan kurang akurat yaitu: Judul BP, BP 1.1, BP 1.2, BP 2.1, dan BP 2.2. Salah satu contohnya sebagai berikut.

\begin{tabular}{|c|l|l|}
\hline $\begin{array}{c}\text { Judul } \\
\text { BP }\end{array}$ & $\begin{array}{l}\text { 臨時国会は12月 } 5 \text { 日まで、政府・与党が調整: } \\
\text { 関係 }\end{array}$ & $\begin{array}{l}\text { Sesi Diet Luar Biasa hingga } 5 \text { Desember, } \\
\text { dikoordinasikan oleh pemerintah dan } \\
\text { pihak yang berkuasa = sumber. }\end{array}$ \\
\hline
\end{tabular}

Terjemahan di atas kurang akurat karena adanya beberapa kekeliruan yaitu:

1. Kata 臨時国会 (Rinji kokkai) diterjemahkan secara kurang akurat menjadi Sesi Diet Luar Biasa. Lebih tepat apabila diterjemahkan menjadi Masa Sidang Parlemen Luar Biasa

2. 与党 (Yotō) merujuk pada partai, bukan sekedar pihak.

Untuk terjemahan tidak akurat terdapat pada: BP 3.1, BP 4.1, dan BP 4.2. Salah satu contohnya sebagai berikut.

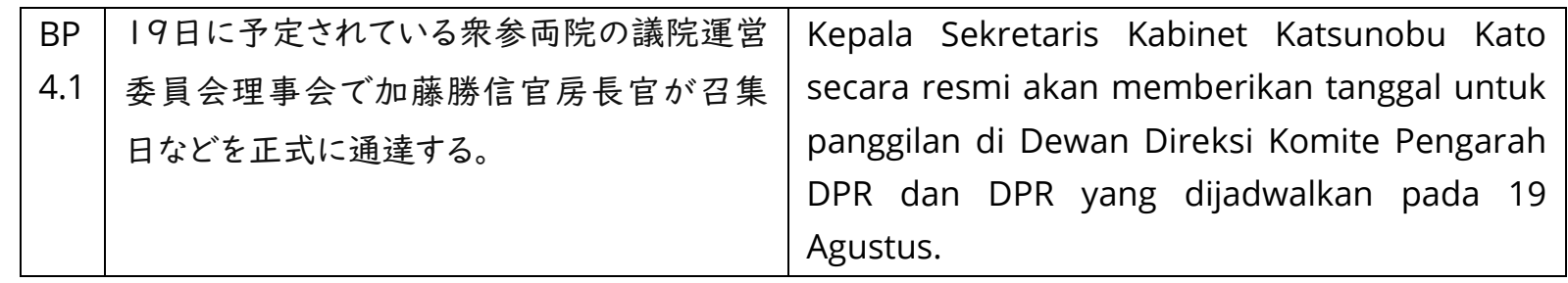

Dalam pengalihan pesannya, terjemahan di atas tidak akurat. Kesalahan terdapat pada:

1. Kata 衆参両院 (Shūsan ryōin) diterjemahkan kurang akurat, seharusnya: Kedua Dewan Parlemen Majelis Rendah dan Majelis Tinggi.

2. 議院運営委員会理事会で(Giin un'ei iinkai riji-kai de) diterjemahkan kurang akurat, seharusnya: Pertemuan Dewan Pengawas parlemen untuk Kedua Dewan Parlemen Majelis Rendah dan Majelis Tinggi.

3. 召集日(Shōshū-bi) diterjemahkan kurang akurat, seharusnya: tanggal undangan pemanggilan

4. Terjemahan kata 通達する (Tsūtatsu suru) lebih akurat menggunakan kata menyampaikan.

5. Tidak ada kata di dalam BSu yang merujuk pada bulan Agustus.

6. Susunan kalimat terjemahan, membuat makna tidak akurat, menimbulkan penafsiran berbeda.

Untuk berita kesehatan, terjemahan yang akurat tidak terdapat satupun data yang termasuk ke dalam kategori akurat. Untuk terjemahan kurang akurat, yaitu pada: BK 2.1, BK 3.1, BK 4.1, dan BK 4.2. Contohnya:

\begin{tabular}{|l|l|llr|}
\hline BK & 加藤官房長官によると、4連休中の航空各社 & Menurut Kepala & Sekretaris Kabinet Kato, \\
2.1 & と新幹線の予約状況は、前年同期比50\%程 & reservasi untuk maskapai dan kereta \\
& 度となり、今年5月の大型連休や旧盆休み期 & shinkansen selama empat hari libur berturut- \\
& 間よりも增えたという。 & turut sekitar 50\% dibandingkan dengan periode \\
& yang sama tahun lalu, peningkatan dari liburan \\
\hline
\end{tabular}




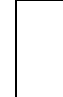
besar berturut-turut dan bekas periode Liburan Bon pada Mei tahun ini.

Kesalahan yang menyebabkan terjemahan BK 2.1 kurang akurat, yaitu:

1. Kata empat hari libur berturut-turut kurang akurat, lebih baik menggunakan kata empat hari liburan akhir pekan panjang.

2. Kata 各社 (kakusha) tidak diterjemahkan jadi mengurangi makna aslinya.

3. Kata 大型連休 (Ōgata renkyū) sebaiknya diterjemahkan menjadi liburan panjang.

4. Kanji 旧 $(K y \bar{u})$ dari kata 旧盆 (Kyūbon) bukan berarti bekas, tetapi penanggalan lunar, beberapa tempat mengggunakan perhitungan penanggalan lunar untuk menentukan tanggal acara obon.

5. Peletakkan bulan Mei pada frasa periode Liburan Bon pada Mei tahun ini tidak tepat, seharusnya diletakkan setelah kata liburan panjang karena melekat di sana (5月の大型連休), dengan salah letak ini bisa menimbulkan dua penafsiran, yaitu:

a. Kedua liburan terjadi pada bulan Mei, atau

b. Liburan bon terjadi pada bulan Mei.

Untuk terjemahan tidak akurat yaitu pada: Judul BK, BK 1.1, dan BK 5.1. Contohnya:

\begin{tabular}{|c|l|l|}
\hline BK & [東京 23日 ロイター $]-$ 加藤勝信官房 & [Tokyo 23rd Reuters] - Kepala Sekretaris Kabinet \\
1.1 & 長官は23日午後の会見で、敬老の日と & Katsunobu Kato mengatakan pada konferensi pers \\
& 秋分の日の祝日を含めた4連休中に多く & pada Rabu sore bahwa ia akan memperhatikan \\
& の人出があったことと今後のコロナ感染 & dengan baik banyaknya orang selama empat hari \\
& 状況に関して、どうなるのか慎重に注視し & libur berturut-turut, termasuk Penghormatan \\
ていくとの見解を示した。 & untuk Hari Tua dan Liburan Hari Musim Gugur, dan \\
& apa yang akan terjadi pada situasi infeksi koronal \\
& di masa depan.
\end{tabular}

Ada beberapa hal yang membuat terjemahan tidak akurat, yaitu:

1. Frasa 23日(ni juu san nichi) kurang akurat, lebih baik ditambah kata tanggal 23.

2. Kata mengatakan kurang akurat, lebih baik menggunakan kata berkata karena tidak diikuti dengan obyek tertentu.

3. Frasa empat hari libur berturut-turut kurang akurat, lebih baik menggunakan kata empat hari liburan akhir pekan panjang.

4. Terjemahan Frasa 23日午後の会見で(ni juu san nichi gogo no kaiken de) yaitu pada konferensi pers pada Rabu sore tidak akurat. Pada BSu tidak ada kata yang menunjukkan hari Rabu, hanya tanggal, dan tanggal tidak diterjemahkan.

5. Frasa 多くの人出(Ōku no hitode) yang diartikan menjadi banyaknya orang kurang akurat, karena tidak hanya semata orang, melainkan orang yang bepergian.

6. Frasa 敬老の日(Keirō no hi) yang diartikan menjadi Penghormatan untuk Hari Tua kurang akurat dan susunan kata juga kurang tepat, harusnya Hari Penghormatan bagi Orang Lanjut Usia.

7. Frasa 秋分の日 (Shūbun no hi) lebih akurat diterjemahkan sebagai Hari Ekuinoks Musim Gugur. 
8. Kata 祝日(Shukujitsu) tidak diterjemahkan dengan baik, hanya dimasukkan pada liburan musim gugur, padahal merujuk pada 2 hari libur yang disebutkan.

9. Penulisan kata koronal pada frasa situasi infeksi koronal di masa depan tidak tepat.

\section{Keberterimaan}

Dari berita ekonomi dari segi keberterimaan, untuk terjemahan berterima tidak ditemukan satupun terjemahan yang berterima. Untuk terjemahan yang kurang berterima. yaitu pada: Judul BE, BE 1.1, BE 1.2, BE 2.1, BE 3.1, BE 3.2, BE 3.3, dan BE 3.4. Berikut salah satu data yang tergolong kurang berterima:

\begin{tabular}{|l|l|l|l|}
\hline $\mathrm{BE}$ & 去年 10 月に行った前回調査では、トップ & Dalam survei sebelumnya yang dilakukan \\
3.3 & が岩手県、2 位沖縄県、3 位熊本県、4 位 & Oktober lalu, Prefektur Iwate, Prefektur Okinawa \\
& 香川県、5 位愛媛県だったが、その内今回 & Juara 2, Prefektur Kumamoto Juara 3, Prefektur \\
& 位以内に残ったのは前回トップの岩手県 & Kagawa ke-4, dan Juara 5 Prefektur Ehime adalah \\
だけだった。 & yang teratas di antara mereka, tetapi hanya \\
& prefektur iwate yang tetap berada di 5 besar kali \\
& ini.
\end{tabular}

Ada beberapa kesalahan yang menyebabkan data BE 3.3 kurang berterima, yaitu:

1. Penulisan prefektur dan nama tempat ada yang tanpa huruf kapital.

2. Sebelum kata Oktober lebih baik diawali dengan kata bulan

3. Kata トップ (toppu) tidak diterjemahkan sehingga kurang utuh.

4. 去年(kyonen) diterjemahkan menjadi lalu, seharusnya tahun lalu.

5. Pemakaian kata juara tidak tepat, karena bukan pertandingan kejuaraan.

Terjemahan tidak berterima pada berita ekonomi yaitu pada: BE 4.1, BE 4.2, dan BE 5.1. Berikut salah satu data yang tergolong tidak berterima:

\begin{tabular}{|c|c|c|}
\hline $\begin{array}{l}\mathrm{BE} \\
4.2\end{array}$ & $\begin{array}{l}\text { 地方が | } 148 \text { 店で全体の } 27.5 \% \text { たたっ } 8 \text { 年前 } \\
\text { に比べると I0.3\%伸びており、地方での免税店 } \\
\text { 普及率が著しい。 }\end{array}$ & $\begin{array}{l}\text { Jumlah toko bebas bea di daerah pedesaan } \\
\text { adalah } 10,3 \% \text { lebih tinggi dari delapan } \\
\text { tahun yang lalu, ketika jumlah toko di } \\
\text { wilayah itu adalah } 27,5 \% \text { dari total. }\end{array}$ \\
\hline
\end{tabular}

Ada beberapa kesalahan yang menyebabkan data BE 4.2 tidak berterima, yaitu:

1. Kata 1148 店で(sen hyaku yon juu hachi mise de) dihilangkan.

2. Istilah daerah pedesaan untuk menerangkan kata 地方(Chihou) tidak berterima, karena memang bukan merujuk pada daerah pedesaan yang ada di Jepang.

3. Kata に比べると(ni kuraberu to) dihilangkan sehingga membingungkan saat membaca maknanya, sangat tidak alamiah.

4. Penggunaan kata itu membuat terjemahan terasa kaku secara keseluruhan dan terkesan tidak alamiah.

Untuk berita politik, terjemahan yang berterima yaitu data BP 1.2. 


\begin{tabular}{|l|l|l|}
\hline $\mathrm{BP}$ & 複数の政府·与党関係者が明らかにした。 & Beberapa pejabat pemerintah dan partai yang \\
1.2 & & berkuasa mengungkapkan masalah ini. \\
\hline
\end{tabular}

Terjemahan diatas sudah sesuai dengan norma, kaidah, dan budaya pada bahasa Indonesia. Untuk data yang termasuk kategori kurang berterima dan tidak berterima, peneliti dan penerjemah ahli memiliki sedikit perbedaan penilaian Judul BP.

\begin{tabular}{|c|l|l|}
\hline $\begin{array}{c}\text { Judul } \\
\text { BP }\end{array}$ & $\begin{array}{l}\text { 臨時国会は12月5日まで、政府・与党が } \\
\text { 調整:関係筋 }\end{array}$ & $\begin{array}{l}\text { Sesi Diet Luar Biasa hingga 5 Desember, } \\
\text { dikoordinasikan oleh pemerintah dan pihak yang } \\
\text { berkuasa = sumber. }\end{array}$ \\
\hline
\end{tabular}

Berikut hasil analisis yang dilakukan oleh penerjemah ahli terhadap Judul BP:

1. Pemakaian kalimat pasif di sini membuat terjemahan kurang akurat, lalu kata (hingga) tidak cocok di sini membuat kesan bahwa acara berlangsung hingga/sampai tanggal 5 Desember.

2. Penggunaan kata partai yang berkuasa lebih pas daripada (pihak yang berkuasa).

3. (Sesi) dalam konteks parlemen kurang pas, terkesan hanya acara biasa

4. Penggunaan kata (Diet) juga kurang pas dalam kaidah bahasa Indonesia, parlemen.

5. Seharusnya terjemahannya menjadi: Pemerintah dan partai yang berkuasa akan mengatur pelaksanaan Sidang Luar Biasa Parlemen sebelum tanggal 5 Desember

Dengan dasar analisis diatas, penerjemah ahli mengelompokkan Judul BP ke dalam kategori kurang berterima dengan skor 2. Peneliti sepakat dengan poin-poin analisis yang dikemukakan oleh penerjemah ahli, namun untuk pengkategorian data, peneliti memiliki penilaian yang berbeda, dengan pertimbangan yaitu: Struktur gramatikal yang masih terpaku pada bahasa Jepang, sehingga tidak sesuai dengan kaidah bahasa Indonesia. Hal ini mengacu pada indikator terjemahan kurang berterima yang menyatakan bahwa: Pada umumnya terjemahan sudah terasa alamiah, namun ada sedikit masalah pada penggunaan istilah atau terjadi sedikit kesalahan gramatikal. Kesalahan gramatikal yang ada pada Judul BP bukan kesalahan yang sedikit, namun keseluruhan kalimat tersebut salah, karena masih terpaku pada sususan gramatikal bahasa Jepang $(B S u)$, sehingga lebih cocok apabila Judul BP termasuk katergori tidak berterima dengan skor 1.

Dalam berita kesehatan tidak ditemukan satupun data yang berterima Untuk yang kurang berterima yaitu pada: Judul BK, BK 1.1, BK 2.1, BK 3.1, BK 4.1, dan BK 4.2. Contohnya:

\begin{tabular}{|l|l|l|}
\hline BK & また、菅義偉首相と小池百合子東京都 & Mengenai pertemuan antara Perdana Menteri \\
4.1 & 知事が23日に会談したことに関し、コ & Yoshihide Suga dan Gubernur Tokyo Yuriko Koike \\
& ロナ感染拡大の防止と経済回復の両 & pada 23 Agustus, Perdana Menteri Yoshihide Suga \\
& 立に向け、緊密に連携していくことを確 & dan Gubernur Tokyo Yuriko Koike menegaskan \\
& 認したと述べた。 & $\begin{array}{l}\text { bahwa mereka akan bekerja sama secara erat untuk } \\
\text { mencegah penyebaran infeksi korona dan mencapai } \\
\end{array}$ \\
& pemulihan ekonomi. \\
\hline
\end{tabular}

Faktor yang membuat terjemahan tersebut kurang berterima, yaitu: 
1. Pengulangan nama Perdana Menteri dan Gubernur dua kali di tempat yang berdekatan, membuat kalimat tidak alamiah. Akan lebih baik menggunakan kata ganti mereka/keduanya pada nama Perdana Menteri dan Gubernur yang terakhir. Sehingga kalimatnya menjadi:

Selain itu, terkait pertemuan antara Perdana Menteri Yoshihide Suga dan Gubernur Tokyo Yuriko Koike pada tanggal 23, mereka menegaskan akan bekerja sama secara erat untuk mencegah penyebaran COVID-19 serta akan mencapai pemulihan ekonomi.

Untuk terjemahan tidak berterima yaitu pada BK 5.1.

\begin{tabular}{|c|l|l|}
\hline BK & 衆院解散の有無とも関連して召集時期が注 & Menanggapi pertanyaan tentang jadwal tertentu \\
5.1 & 目されている臨時国会について、与党内で具 & dalam partai yang berkuasa mengenai sesi Diet \\
& 体的な日程に関する案が出ているとの質問 & yang luar biasa, yang menarik perhatian karena \\
& に対し、加藤官房長官は「どういう話か承知 & pembubaran DPR，Kepala Sekretaris Kabinet \\
& していない」と述べるにとどまった。 & Yoshihide Kato mengatakan, "Saya tidak \\
& menyadari apa ceritanya nanti."
\end{tabular}

Secara keseluruhan terjemahan terasa membingungkan karena tidak beraturan, terdapat kalimat yang diterjemahkan tidak secara utuh, dan kata 承知していない (Shōchi shite inai) lebih baik diterjemahkan menjadi mengetahui. Terjemahan akan lebih berterima apabila disusun ulang menjadi: Yang paling menyita perhatian adalah menengenai apakah Majelis Rendah akan dibubarkan atau tidak, juga terkait Sidang Parlemen Luar Biasa. Ketika ditanya apakah di internal partai berkuasa ada usulan tanggal pastinya, Kepala Sekretaris Yoshihide Kato berkata "Saya tidak menegtahui hal tersebut".

\section{Keterbacaan}

Dari berita ekonomi dari segi keterbacaan, untuk tingkat keterbacaan tinggi. Dalam berita ekonomi yang dianalisis, hanya terdapat 2 data yang termasuk dalam kategori ini, yaitu data BE 1.1 dan BE 3.2

\begin{tabular}{|c|l|l|}
\hline $\mathrm{BE}$ & 観光庁は 6 月 17 日、2020 年 3 月 31 日時点 & Pada 17Juni 2020, Badan Pariwisata Jepang \\
1.1 & $\begin{array}{l}\text { での都道府県別消費税免税店数をとりまとめ、発 } \\
\text { 表した。 }\end{array}$ & $\begin{array}{l}\text { menyusun dan mengumumkan jumlah } \\
\text { toko bebas pajak konsumsi berdasarkan } \\
\text { prefektur per 31 Maret 2020. }\end{array}$ \\
\hline
\end{tabular}

Terjemahan BE 1.1 terbaca dengan baik, tidak perlu membaca berulang kali untuk memahami maksud dari kalimat tersebut dan secara gramatikal tidak ada masalah. Untuk keterbacaan sedang. Terdapat 6 data berita ekonomi yang masuk dalam kategori ini, yaitu: Judul BE, BE 1.2, BE 2.1, BE 3.1, BE 3.3, BE 3.4. Berikut salah satu data yang termasuk memiliki tingkat keterbacaan sedang:

\begin{tabular}{|c|c|c|}
\hline $\mathrm{BE}$ & 長崎が全都道府県において飛び抜けた伸び & Nagasaki mencatat tingkat pertumbuhan yang \\
\hline 3.4 & $\begin{array}{l}\text { 率を記録したが、2 位以下は東北の活躍が目 } \\
\text { 立った。 }\end{array}$ & $\begin{array}{l}\text { melonjak melalui semua prefektur, tetapi } \\
\text { keberhasilan Tohoku mencolok di tempat } \\
\text { kedua atau lebih rendah. }\end{array}$ \\
\hline
\end{tabular}


Kata melalui membuat kalimat agak sulit dipahami sehingga kalimat harus dibaca lebih dari satu kali agar dapat dipahami maksudnya. Sebaiknya kata tersebut diganti dengan melampaui agar lebih mudah dipahami. Atau keseluruhan kalimat diubah menjadi:

\section{Nagasaki mencatat tingkat lonjakan pertumbuhan yang melampaui seluruh prefektur, tetapi untuk tempat kedua dan selanjutnya aktivitas Tohoku terlihat mencolok.}

Untuk keterbacaan rendah, yaitu terjemahan yang sulit dipahami atau bahkan tidak dapat dipahami dan dibaca. Dalam penelitian ini terdapat tiga data berita ekonomi yang termasuk kategori ini, yaitu: BE 4.1, BE 4.2, dan BE 5.1. Contohnya:

\begin{tabular}{|c|c|c|}
\hline $3 E$ & & iqa \\
\hline 41 & $\begin{array}{l}\text { 体の割合の } 62.2 \% \text { 占め、地方が } 37.8 \% \text { とな } \\
\text { った。 }\end{array}$ & $\begin{array}{l}\text { provinsi ini adalah } 62,2 \% \text { dari total, } \\
\text { sementara tiga wilayah metropolitan } \\
\text { menyumbang } 37,8 \% \text {. }\end{array}$ \\
\hline
\end{tabular}

Terjemahan di atas sama sekali tidak dapat dibaca dengan jelas. Selain akibat dari kesalahan keakuratan pengalihan pesan, kata tunjuk ini membuat keseluruhan kalimat menjadi ambigu. Karena tidak disebutkan provinsi mana yang dirujuk oleh kata ini tersebut.

Pada berita politik, terjemahan dengan keterbacaan tinggi ditemukan sebanyak 3 data yaitu: BP 1.2, BP 2.1, dan BP 2.2. Contohnya:

\begin{tabular}{|l|l|l|}
\hline BP & 菅義偉首相就任後初めての所信表明 & Pidato kebijakan pertama sejak pelantikan Perdana \\
2.2 & 演説が行われる。 & Menteri Yoshihide Suga akan disampaikan. \\
\hline
\end{tabular}

Terjemahan BP 2.2 sangat mudah untuk dibaca, bahkan hampir tidak seperti karya terjemahan yang dihasilkan mesin penerjemah pada umumnya. Selanjutnya, dari hasil analisis yang dilakukan tidak ditemukan satupun data yang memiliki tingkat keterbacaan sedang. Untuk keterbacaan rendah. Dalam penelitian ini ditemukan sebanyak 5 data yang termasuk ke dalam kategori ini, yaitu: Judul BP, BP 1.1, BP 3.1, BP 4.1, dan BP 4.2. Contohnya:

\begin{tabular}{|l|l|l|}
\hline BP & 当初は会期をI2月10日前後までとす & Awalnya, rencana untuk menetapkan sesi yang akan \\
3.1 & る案も浮上していたが、।I月中にも首 & diadakan hingga sekitar 10 Desember telah muncul, \\
& 相が正式に策定を指示するとみられる & tetapi diharapkan untuk bergerak maju ke akhir sesi \\
& 2020年度第3次補正予算などの準備 & dengan mempertimbangkan pekerjaan persiapan \\
& 作業に配慮し、会期末を前倒しする格 & seperti anggaran tambahan ke-3 untuk tahun fiskal \\
& 好だ。 & akan segera dirumuskan pada akhir November. \\
\hline
\end{tabular}

Terjemahan BP 3.1 selain tidak akurat, tidak berterima, juga tidak dapat dibaca dengan baik sehingga sulit dipahami. Ada banyak hal yang harus diperbaiki dari terjemahan diatas. 
Untuk berita kesehatan sendiri, data yang termasuk kategori keterbacaan tinggi dan keterbacaan sedang, peneliti dan penerjemah ahli memiliki sedikit perbedaan penilaian pada dua data, data yang dimaksud disini yaitu BK 4.1 dan BK 4.2.

\begin{tabular}{|c|l|l|}
\hline BK & また、菅義偉首相と小池百合子東京都知事が & Mengenai pertemuan antara Perdana Menteri \\
4.1 & 23日に会談したことに関し、コロナ感染拡大の & Yoshihide Suga dan Gubernur Tokyo Yuriko \\
& 防止と経済回復の両立に向け、緊密に連携し & Koike pada 23 Agustus, Perdana Menteri \\
& ていくことを確認したと述べた。 & $\begin{array}{l}\text { Yoshihide Suga dan Gubernur Tokyo Yuriko } \\
\text { Koike menegaskan bahwa mereka akan } \\
\end{array}$ \\
& & $\begin{array}{l}\text { bekerja sama secara erat untuk mencegah } \\
\text { penyebaran infeksi korona dan mencapai } \\
\text { pemulihan ekonomi. }\end{array}$ \\
\hline BK & さらに来年の「東京五輪開催に向けて準備を & $\begin{array}{l}\text { Selain itu, dia berkata, "Kami sepakat untuk } \\
\text { mempersiapkan Olimpiade Tokyo tahun } \\
\text { depan." }\end{array}$ \\
\hline
\end{tabular}

Dalam analisisnya, penerjemah ahli memberikan penjelasan pada BK 4.1 yaitu: Agak mudah dipaham.cPoin-poin utama kalimat asal tersampaikan dengan cukup baik, jadi bisa dipahami dan untuk data BK 4.2 penjelasan yang diberikan penerjemah ahli, yaitu: Agak mudah dipahami. Kalimat ini pendek, hasil terjemahannya tidak terlalu membingungkan . Dengan dasar analisis diatas, penerjemah ahli mengelompokkan BK 4.1 dan BK 4.2 ke dalam kategori tingkat keterbacaan sedang dengan skor 2 .

Peneliti kurang sepakat dengan penerjemah ahli, Peneliti sendiri memiliki penilaian yang berbeda, dengan pertimbangan yaitu: Kata, frase, klausa, dan kalimat terjemahan dapat dipahami dengan mudah oleh pembaca, sehingga tidak cocok apabila dikatergorikan pada tingkat keterbacaan sedang. Hal ini mengacu pada indikator terjemahan tingkat keterbacaan tinggi yang menyatakan bahwa: Kata, frasa, klausa, dan kalimat terjemahan dapat dipahami dengan mudah oleh pembaca. Peneliti berpendapat bahwa BK 4.1 dan BK 4.2 dapat dimengerti hanya dengan sekali baca sehingga lebih cocok masuk kategori tingkat keterbacaan tinggi dengan skor 3.

Untuk tingkat keterbacaan rendah, ditemukan 4 data yang termasuk kategori ini, yaitu: Judul BK, BK 2.1, BK 3.1, dan BK 5.1. Contohnya:

\begin{tabular}{|l|l|l|}
\hline BK & 衆院解散の有無とも関連して召集時期が注 & Menanggapi pertanyaan tentang jadwal tertentu \\
5.1 & 目されている臨時国会について、与党内で & dalam partai yang berkuasa mengenai sesi Diet \\
& 具体的な日程に関する案が出ているとの質 & yang luar biasa, yang menarik perhatian karena \\
& 問に対し、加藤官房長官はどういう話か承 & pembubaran DPR, Kepala Sekretaris Kabinet \\
& 知していない」と述べるにとどまった。 & Yoshihide Kato mengatakan, "Saya tidak \\
& & menyadari apa ceritanya nanti." \\
\hline
\end{tabular}

Istilah yang digunakan pada BK 5.1 tidak familiar bagi pembaca BSa, serta susunan gramatikal yang tidak beraturan membuat kalimat secara keseluruhan tidak dapat dimengerti sama sekali walaupun sudah dibaca berulang kali. 


\section{KESIMPULAN}

Dari hasil analisis dan evaluasi pada bagian sebelumnya tentang kualitas hasil terjemahan Bing Translator dalam menerjemahkan teks berbahasa Jepang ke dalam bahasa Indonesia dapat disimpulkan bahwa: (1) dari segi keakuratan, berita ekonomi, berita politik, dan berita kesehatan termasuk kategori kurang akurat. Sebagian besar dari kekurang-akuratan terjemahan dari ketiga berita tersebut disebabkan oleh pemadanan kata yang kurang tepat; (2) dari segi keberterimaan, berita ekonomi dan berita kesehatan termasuk ke dalam kategori kurang berterima, sedangkan berita politik masuk kedalam kategori tidak berterima. Sebagian besar kekurang-berterimaan terjemahan dari berita ekonomi dan berita kesehatan disebabkan oleh penggunaan istilah yang kurang familiar bagi pembaca BSa pada bagian tertentu. Mayoritas ketidak-berterimaan terjemahan dari berita politik disebabkan oleh penggunaan istilah yang kurang familiar bagi pembaca $B S a$ serta susunan gramatikal yang masih mengikuti BSU sehingga terkesan kaku dan sangat tidak alamiah. (3) Dari segi keterbacaan, berita ekonomi termasuk ke dalam kategori keterbacaan sedang, berita politik dan berita kesehatan termasuk ke dalam kategori keterbacaan rendah. Keterbacaan sedang pada berita ekonomi disebabkan oleh adanya sedikit kesalahan pada struktur gramatikal dan penggunaan istilah yang kurang familiar pada beberapa bagian, sehingga terjemahan harus dibaca lebih dari satu kali agar dapat dimengerti. Keterbacaan rendah pada berita politik dan berita kesehatan disebabkan oleh kesalahan penyusunan kata, penggunaan istilah yang tidak familiar, serta ketidaktepatan penggunaan konjungsi kata. 


\section{DAFTAR RUJUKAN}

Atkinson, P. (1991). Supervising the text. International Journal of Qualitative Studies in Education, 4, 161-174. https://doi.org/10.1080/0951839910040205

Bollinger, D, Donald. A. sears. (1981). Aspect of language third edition. New York: Harcourt brace Jovanovich.

Danyati, R. (2012). Analisis Kesepadanan dan Keberterimaan Bahasa Informal Pada Terjemahan Mesin. Bandung : Lembaga Penelitian dan Pengabdian Masyarakat Bina Sarana Informatika.

Digima News. (2015). Kaigai bijinesu ni toku-ka shita media "DIGIMA nyūsu" tanjō. bijinesu hinto mansai no genchi saishin nyūsu kara nikkei kigyō no shinshutsu dōkō made. Diakses tanggal 10 November 2020 dari https://www.valuepress.com/pressrelease/151658

EAMT, Rosetti A, O'Brien S, Cadwell P.(2020). Comprehension and Trust in Crises: Investigating the Impact of Machine Translation and Post-Editing. Proceedings of Annual Conference of the European Association for Machine Translation, Online, 3-5 November (hal.10-15).

Glaser, B.G. (1992). Emergence vs Forcing: Basics of Grounded Theory Analysis. California: Sociology Press.

Sutopo, H.B. (2006). Metodologi Penelitian Kualitatif : Dasar teori dan Terapannya dalam Penelitian. Surakarta: Universitas Sebelas Maret.

Hanks, P. (1979). Collins Dictionary of the English Language. Glasgow: Harper Collins.

Hartono, R. (2017). Pengantar IImu Terjemahan (Teori dan Praktek). Semarang : Cipta Prima Nusantara.

Holmes, James S. (1972). The Name and Nature of Translation Studies. Amsterdam: Rodopi.

Hutchins, W. J. dan Somers, H. L. (1992). An Introduction to Machine Translation. London: Academic Press.

ICD Translation. (2019). Common Types of Translation Services. Diakses tanggal 30 Desember 2020 dari http://icdtranslation.com/common-types-of-translationservices/

Kusumo, D.W, \& Wardani, D.K. (2019). Ragam Penelitian Dalam Studi Penerjemahan. Malang : Jurnal Linguistik Terapan Politeknik Negeri Malang.

Larson, Mildred L. (1984). Meaning-Based Translation: A Guide to Cross Language Equivalence. America: University of America.

LISA. (2010). LISA Best Practice Guides: Implementing Machine Translation. Diakses tanggal 10 November 2020 dari http://www.lisa.org/LISA-QA-Model-31.124.0.html

Machali, R. (2000). Pedoman Bagi Penerjemah. Jakarta: Grasindo. 
Microsoft Translator. (2016). Translator Solutions in Action: Localization Tools and Services. Diakses tanggal 10 November 2020 dari https://www.microsoft.com/enus/translator/blog/author/mtteam/page/13/

Moleong, L. J. (2010). Metodologi Penelitian Kualitatif. Bandung: Remaja.

Munday, J. (2008). Introducing Translation Studies: Theories and Applications. London: Routledge.

Nababan (2003). Teori Menerjemah BS. Yogyakarta: Percetakan Pelajar.

Nababan (2004). Laporan Penelitian, Keterkaitan antar latara Belakang Penjermahan dan kualitas terjemahan. Surakarta: Universitas Sebelas Maret.

Nababan, M, dkk , (2012). Pengembangan Model penilaian Kualitas Terjemahan. Kajian Linguistik dan Sastra, 24 (1), hal. 44.

Newman, J. D. (2016). Human performance tool spotlight: peer-checking. Human Performance Tools for Practitioners. Diakses tanggal 10 November 2020 dari https://www.humanperformancetools.com

Nida, Eugene A, \& Taber, Charles R. (1974). The Theory and Practice of Transalation. UBS: Leiden.

Ridha, H. (2011). Kualitas Mesin Penerjemah Statistik (Studi terhadap Terjemahan Dokumen Berita Aljazeera.net menurut Ahli dan Pembaca Awam). (Skripsi). Universitas Syarif Hidayatullah, Jakarta, Indonesia.

Romli, Asep S.M. (2009). Jurnalistik Praktis. Bandung: Remaja Rosdakarya

Sukadji, S. (2000). Menyusun dan Mengkaji Laporan Penelitian. Jakarta: Universitas Indonesia.

Toury, G. (1995). Descriptive Translation Studies And Beyond. Amsterdam: John Benjamins.

Waskito, N.A. (2016). Kesalahan Kebahasaan Hasil Terjemahan Google - Translate Teks Bahasa Jepang ke Dalam Bahasa Indonesia. (Skripsi). Universitas Brawijaya, Malang, Indonesia. 
62 | DOI: 10.33479/klausa.v4i02.408 